\title{
Investigation of Index Properties of a Residual Soil Profile
}

\author{
${ }^{1}$ Mohammed, K. A., ${ }^{2}$ Yisa, G. L., ${ }^{3}$ Sule Emmanuel And ${ }^{4}$ Makwin, H. L. \\ ${ }^{1234}$ nigeria Building and Road Research Institute, Ota, Ogun State.
}

\begin{abstract}
This research investigates the index properties of a residual soil profile at Bosso campus of the Federal University of Technology, Minna. A trial pit was dug to a depth of $3 \mathrm{~m}$ and disturbed soil samples were taken at depths of $0.5,1,1.5,2,2.5$ and $3 \mathrm{~m}$ respectively. Natural moisture content (NMC) test, Atterberg limit test, mechanical sieve analysis and hydrometer test, specific gravity and standard proctor compaction test were carried out on each sample. By visual inspection it was observed that the soil profile consists of three layers; light reddish at the top, reddish soil at the middle and whitish soil at the bottom respectively. The natural moisture content increased from $2.3 \%$ to $15.3 \%$ at $0.5 \mathrm{~m}$ to $1.5 \mathrm{~m}$ depth and decreased to $11.8 \%$ at 2 $m$ depth after which it increased to $15.8 \%$ at $3 m$ depth. Using the unified soil classification system (USCS), the top and middle layer were classified as well graded sand $(S W)$ while the bottom layer was classified as clayed sand (SC). The optimum moisture content (OMC) decreased from $10.8 \%$ to $7.2 \%$ at $0.5 \mathrm{~m}$ to $2.0 \mathrm{~m}$ depth then increased to $7.8 \%$ at $2.5 \mathrm{~m}$ depth and decreased to $7.2 \%$ at $3 \mathrm{~m}$ depth. The maximum dry density (MDD) decreased from $1.99 \mathrm{Mg} / \mathrm{m}^{3}$ to $1.92 \mathrm{Mg} / \mathrm{m}^{3}$ at $0.5 \mathrm{~m}$ to $1 \mathrm{~m}$ depth, it increased to $2.1 \mathrm{Mg} / \mathrm{m}^{3}$ at $2 \mathrm{~m}$ depth, it then decreased to $1.95 \mathrm{Mg} / \mathrm{m}^{3}$ and increased to $2.1 \mathrm{Mg} / \mathrm{m}^{3}$ at $3 \mathrm{~m}$. Based on these investigations, the index properties of the residual soil profile of the pit varies with depth.
\end{abstract}

Keywords: Index properties, Residual soil, Soil profile, Undisturbed soil, Lateritic soil

\section{Introduction}

For soil to be suitable in civil engineering project, it must meet existing local requirement for index properties in addition to certain strength criteria. Typical specifications limit of these properties to some threshold values which in most cases are project specific (Agapetus, 2010). Soils are formed through the interaction of five major factors, Time, Climate, Parent material, Topography and relief, and Organism. The relative influence of each factor varies from place to place, but the combination of all five factors normally determines the kind of soil developing in a given place (Plymouth, 2010) Generally soil may be classified according to the method of formation as residual, transported and organic soil. Residual soil is one formed "insitu" by chemical weathering and may be found on level rock surface where the action of the element has produced a soil with little tendency to move. These include top soil and lateritic soil (Smith et. al, 1998)

Lateritic soils are widely used as fill material for various construction works in most tropical countries. These soils are weathered under condition of high temperatures and humidity with defined alternating wet and dry season resulting in poor engineering properties as high plasticity poor workability, low strength, high permeability, tendency to retain moisture and high natural moisture content (Gidigasu, 1976).

Many soil workers in Nigeria may treat lateritic weathering product and other residual soil as uniform with depth. This is the main reason why single test or few soil test results carried out on a soil in a trial pit at the beginning of excavation is used to represents soil at deeper depth of the borrow pit. They are not mindful of the composite and complex nature of the weathering materials and the variation in the morphological, geotechnical mineralogical and chemical properties of the materials with depth of the weathering profile. (Adekoya, 1987)

Therefore to neglect the changes in the index properties of residual soil with depth may lead to misleading result and consequently serious failure of geotechnical engineering structure. This work is therefore aimed at investigating the index properties of residual soil found at bosso campus of Federal University of Technology, Minna.

\section{Material And Method}

A trial pit was dug to a depth of $3 \mathrm{~m}$ at the Bosso campus of the Federal University of Technology, Minna. Disturbed soil samples were collected at $0.5 \mathrm{~m}, 1 \mathrm{~m}, 1.5 \mathrm{~m}, 2 \mathrm{~m}, 2.5 \mathrm{~m}$ and $3 \mathrm{~m}$ depth. During the digging, the soil profile was visually inspected. Disturbed sample were air dried and test including natural moisture content, mechanical seive analysis and hydrometer analysis,liquid limit (LL), plastic limit (PL), specific gravity (SG) and compaction were carried out according to procedure highlighted in BS1377 1997. 


\subsection{Visual Inspection}

\section{Result And Dicussion Of Result}

The profile of the trial pit showed a light blackish top soil with thickness $0.4 \mathrm{~m}$ below this layer was observed that the profile consist of three layer. Light reddish silty to sandy bellow the top soil with thickness of $1.8 \mathrm{~m}$. Followed by a reddish lateritic soil layer with little gravel of thickness of $0.8 \mathrm{~m}$ while at the last layer it was whitish sand with little fine thickness of $0.5 \mathrm{~m}$

\subsection{Natural Moisture Content}

The result of natural moisture content of samples from the trial pit showed that the soil sample at $0.5 \mathrm{~m}$ cannot hold water, it has low moisture contents of $2.3 \%$. The natural moisture content increased to $15.3 \%$ at $1.5 \mathrm{~m}$ and decreased to $11.8 \%$ at $2 \mathrm{~m}$, after which it increased to $15.8 \%$ at $3 \mathrm{~m}$.

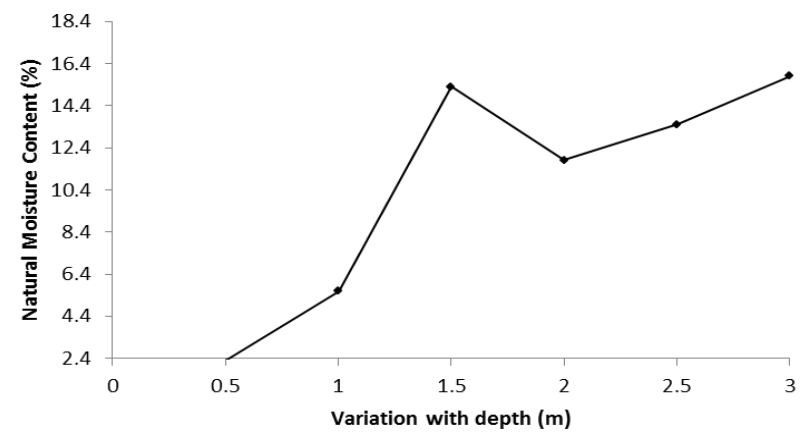

Fig. 1: Natural moisture content graph

\subsection{Particle Size Distribution Analysis}

According to the unified soil classification system, at $0.5 \mathrm{~m}$ the soil is sandy fine and medium residual soil with traces of coarse aggregate, more of coarse than fine. It is a well graded sand, with little fine (SW). At 1.0, $1.5 \mathrm{~m}$, the soil is sandy, fine and medium residual soil more of coarse than fine. It is well graded sandy gravel with little fine (SG). At 2 to $3 \mathrm{~m}$, the soil is sandy and medium residual soil with traces of coarse aggregate. It is more of fine than coarse, it is clay sand poorly graded of sand clay mixture (SC). This show a distinct three weathering profile.

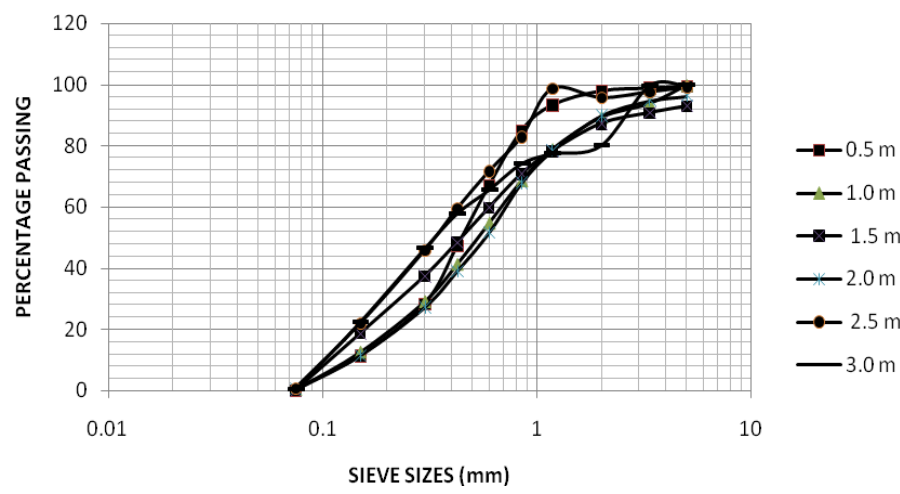

Fig. 2: Particle size distribution graph

\subsection{Atterberg Limit}

Atterberg limit are particularly useful indices often used directly as specifications for controlling soil for used in engineered fills. The LL is a measure of the water content at which soil behave practically like liquid but has a small shear strength, the PI indicates the magnitude of water content range over which the soil remains plastic, in general terms, the higher the plasticity index the higher the potential to shrink as the soil undergoes moisture content fluctuation.

The result showed that there is increase in liquid limit from $22.53 \%$ to $27.6 \%$ at $0.5 \mathrm{~m}$ to $1 \mathrm{~m}$ from where a deviation was observed resulting to a decreased to $26.8 \%$ at $1.5 \mathrm{~m}$ and increase to $28.2 \%$ at $2 \mathrm{~m}$. It was also observed that LL decrease to $25.8 \%$ at $3 \mathrm{~m}$. The plastic limit is equal to 0 at $0.5 \mathrm{~m}$ which decreased from $17.5 \%$ at $1 \mathrm{~m}$ to $4.6 \%$ at $3 \mathrm{~m}$. The soil in this trial pit was classified as low plasticity. 


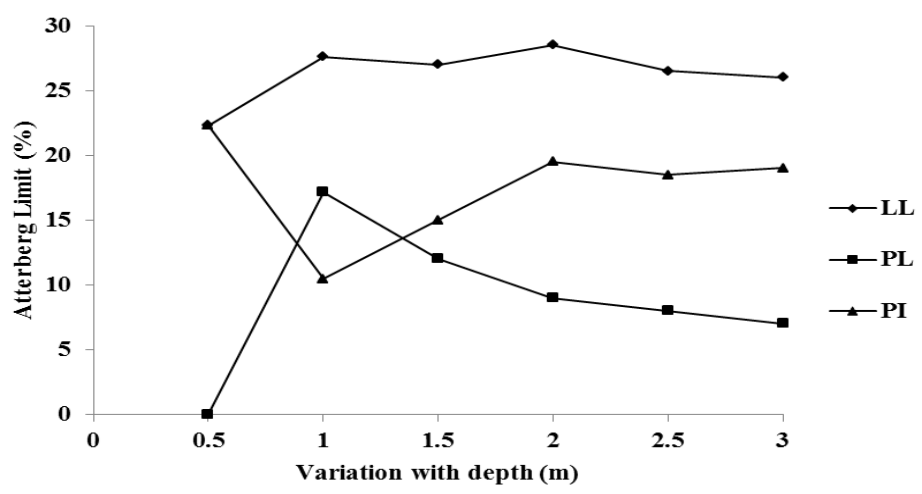

Fig. 3: Variation of Atterberg limit with soil depth

\subsection{Specific Gravity}

The specific gravity increased from 2.5 at $0.5 \mathrm{~m}$ to 2.65 at $2.5 \mathrm{~m}$ and $3 \mathrm{~m}$ depths respectively. This is probably due to presence of free iron in this depth which is heavier than soil particles.

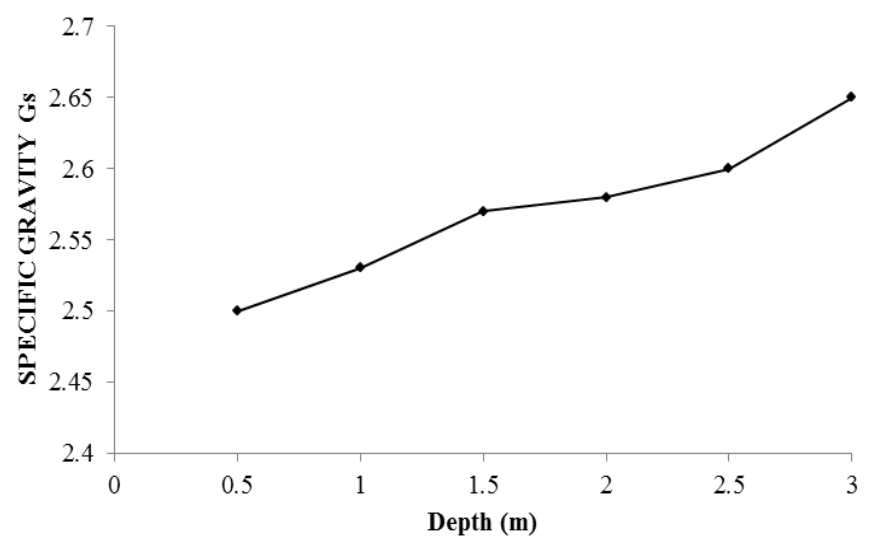

Fig. 4: Variation of specific gravity with soil depth

\subsection{Compaction Charateristics} figure below.

The relationship between moisture content and dry density varies with various depths are shown in the

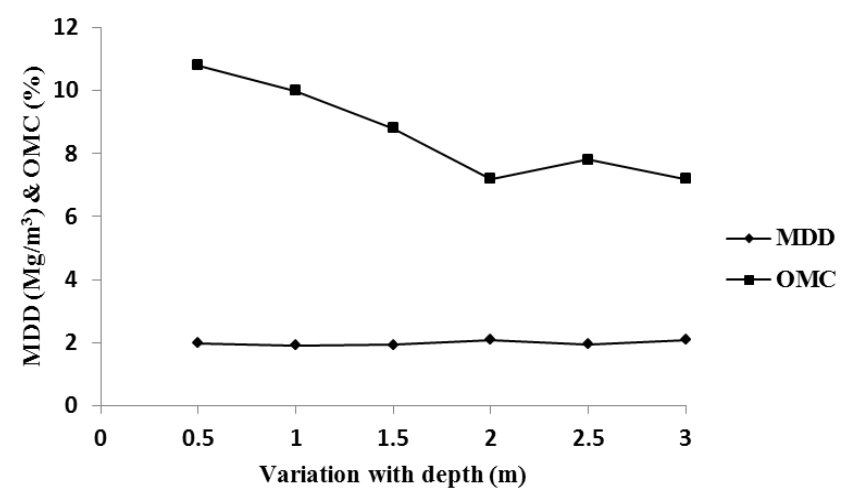

The dry densities of samples compacted at British standard light compaction energy level however, decreased from $1.99 \mathrm{Mg} / \mathrm{m}^{3}$ at $0.5 \mathrm{~m}$ depth to $1.92 \mathrm{Mg} / \mathrm{m}^{3}$ at $1 \mathrm{~m}$ depth while it increased to $1.93 \mathrm{Mg} / \mathrm{m}^{3}$ and $2.1 \mathrm{Mg} / \mathrm{m}^{3}$ at $1 \mathrm{~m}, 2 \mathrm{~m}$ depth respectively. It thereafter decreased to $1.94 \mathrm{Mg} / \mathrm{m}^{3}$ at $3 \mathrm{~m}$ depth. The optimum moisture content decreased $10.8 \%$ to $7.2 \%$ from $0.5 \mathrm{~m}$ to $2.5 \mathrm{~m}$ while it increased at $3 \mathrm{~m}$ to $7.3 \%$.

\section{Conclusion}

This study investigated changes in some physical properties of residual soil profile formation of a trial pit located in Minna. It was observed that the soil profile consist of reddish lateritic soil having a thickness of 
about $0.7 \mathrm{~m}$ to $1.6 \mathrm{~m}$ between a light reddish silty to sandy and whitish sandy with little fine. Natural moisture content increased from $0.5 \mathrm{~m}$ to $2 \mathrm{~m}$ after which a decrease was noticed and further increased down to a depth of $3 \mathrm{~m}$. The particle size distribution generally, showed higher percentage of coarse soil at the reddish lateritic layer and higher percentage of clay size at the layer just beneath the lateritic soil layer. The maximum densities increased and decreased at various layer down the profile. It recorded higher dry density at lateritic layer and higher OMC at the top layer.

Based on this investigation, the index proprieties of the residual soils studied varies with depth at one layer and therefore should not be used to represent the result of soils at other layers for the avoidance of inaccurate design of soil structures which may lead to its failure on application of the first load.

\section{References}

[1]. Smith, G. N and Smith, I. G. N. (1998). Element of soil mechanics Blackwell Publisher, London Seventh Edition pp. 477

[2]. Maigien, R. (1966). Review of research on laterites. Natural Resources Research IV, United Nations Education Scientific and Cultural Organization, Paris

[3]. Gidigasu, M. D. (1976). Lateritc Soil Engineering, Elsevier Scientific Publishing Co, New York.

[4]. Chairman, J. H. (1988). Laterite in road pavements. Construction Industry Research and Information Association (CIRCA), special publication 47, West Minister, London.

[5]. Adekoya, J. A. (1987). A preliminary geological and geotechnical study of Nigeria proceedings of the $9^{\text {th }}$ Regional Conference for Africa on soil mechanics and foundation engineering, Akinmusuru, J.O, malomo, ss. And sesida, E A .(esd), lagos, Nigeria, 15 17 september, A.A balvema rotter dami the Netherlands. Pp 21 -30

[6]. BRR1/ lyon 1971 associates, laterites and lateritic soil pf Africa. An engineering study for USALD AID /CSD - 2/64 balt more, md.

[7]. Ola, S. A. (1983). Geotechnical properties and behavior of some Nigerian lateritic soils in tropical soils of Nigeria in engineering practice, ed.a ola balleema, Rotterdam.

[8]. British standard BS 1377 (1990). Method of testing soil for civil engineering purposes. British Standards Institute BSI, London, UK.

[9]. Agapetus, A. (2010). Evaluation of changes of in index properties of lateritic soil

stabilized with fly ash. Leonardo Electronic Journal of Practices and Technology, pp74

[10]. Plymouth county soil survey update 